\title{
Effect of Family Hope Program on Maternal Health Behavior and Children Under Five Nutritional Status in Poor Families, Jombang, East Java
}

\author{
Sintya Rosalina'), Endang Sutisna Sulaeman²), Bhisma Murti 1) \\ 1)Masters Program in Public Health, Universitas Sebelas Maret \\ 2)Department of Public Health, Faculty of Medicine, Universitas Sebelas Maret
}

\begin{abstract}
Background: Family Hope Program, or internationally referred to as Conditional Cash Transfer (CCT), is a government poverty allevation initiative by provision of conditional cash money that induces healthy behavior so as to achieve strong generation. This study sought to examine the effect of Family Hope Program on maternal health behavior and children under five nutritional status in poor families, Jombang, East Java.

Subjects and Method: This was an analytic observational study with retrospective cohort design. This study was conducted in Jombang District, East Java, from November to December 2017. A total sample of 210 mothers and their children under five were selected for this study by fixed exposure sampling. The dependent variables were maternal health behavior and child nutritional status. The independent variables were birthweight, history of illness, maternal education, family income, family support, government Family Hope Program, and access to health service. The data were collected by maternal and child book record and questionnaire. The data were analyzed by path analysis.

Results: The likelihood of good nutritional status of children under five increased with good nutritional intake $(b=1.9 ; 95 \% \mathrm{CI}=1.1$ to $2.8 ; \mathrm{p}<0.001)$, normal birthweight $(\mathrm{b}=2.5 ; 95 \% \mathrm{CI}=0.9$ to $4.1 ; p=0.002)$, rare frequency of illness $(b=1.3 ; 95 \% \mathrm{CI}=0.5$ to $2.1 ; \mathrm{p}=0.001)$, and strong family support $(b=1.5 ; 95 \% \mathrm{CI}=0.6$ to $2.3 ; \mathrm{p}<0.001)$. The likelihood of maternal healthy behavior increased with Family Hope Program ( $b=4.1 ; 95 \% \mathrm{CI}=3.1$ to $5.0 ; \mathrm{p}<0.001)$ and higher maternal education $(\mathrm{b}=1.9 ; 95 \% \mathrm{CI}=0.9$ to $2.8 ; \mathrm{p}<0.001)$. Good nutritional intake increased with maternal healthy behavior $(b=0.4 ; 95 \% \mathrm{CI}=-0.04$ to $0.85 ; \mathrm{p}=0.074)$ and strong family support $(\mathrm{b}=0.6$; $95 \% \mathrm{CI}=0.2$ to $1.1 ; \mathrm{p}=0.004)$.

Conclusion: The likelihood of good nutritional status of children under five increases with good nutritional intake, normal birthweight, no history of illness over the past three months, and strong family support. Family Hope Program induces maternal health behavior, increases child nutritional intake, and eventually improves child nutritional status.
\end{abstract}

Keywords: child nutritional status, maternal health behavior, Family Hope Program

\section{Correspondence:}

Sintya Rosalina. Masters Program in Public Health, Universitas Sebelas Maret, Jl. Ir. Sutami 36 A, Surakarta 57126, Central Java. Email: sintya.rosalina@gmail.com. Mobile 085732761747.

\section{BACKGROUND}

Indonesia's poor population reached $\mathbf{2 7 . 7 6}$ million people (10.70 percent) in September 2016, with the largest percentage of poor people which is in Java for about 14.84 million people (53.4\%) (BPS, 2014). Poverty is closely related to health problems, with low health status affecting the productivity of the economy. On the other hand, poverty causes inadequate health services so that there is no improvement on the health status (Adisasmito, 2008).

Indonesian Government has implemented the Family Hope Program (PKH) under the name of International with Conditional Cash Transfer (CCT) since 
2007 as an effort to tackle poverty through conditional cash transfers (Kemsos, 2016).

Providing cash transfers directly to poor communities contributes significantly to public health priority goals, particularly in health services, maternal and child health, and health equity (Forde et al., 2011). Health access provided is expected to change the behavior of poor people to be more concerned in improving access and quality of health services (Kemsos, 2016)

The nutritional status of children under five is an excellent indicator of quality of life. Nutritional status is a key instrument for assessing health conditions (Oliveira et al., 2013). Nutrition plays an important role in maintaining the cellular integrity of the body, in the event of nutritional complications contributing to morbidity and mortality (Suskind and Lenssen, 2013).

Malnutrition is a contributing factor that underlies deaths of about $45 \%$ of children, which makes children more vulnerable to serious illness (WHO, 2016). Malnutrition brings very destructive effects on the future of the child including delayed motor development, impaired cognitive function, lower IQ, and poor school performance (Hoddinott et al, 2011).

The double burden of malnutrition occurs in poor communities (Lesiapeto, 2009). Factors that affect nutritional status include food consumption, knowledge of parents' education about health, socioeconomic conditions, social factors and population conditions, health services and low birth weight that in adulthood susceptible to growth problems (Sofian, 2011; Perry \& Potter, 2005).

The 3rd objective of Sustainable Development Goals (SDGs) is to put an end to preventable infant and children under the age of 5 (WHO, 2015). Children are at greater risk of dying before the age of 5 if they are born in poor family (WHO, 2016).

The gap of child mortality rates between high and low income countries is huge. By 2015, under-five mortality rates in low-income countries are 76 deaths per 1,000 live births, which is about 11 times the average rate in high-income countries (7 deaths per 1000 live births). Reducing injustice throughout the country and saving more children's lives is an important priority (WHO, 2015).

The integrated data of Indonesia's poor handling program shows that the highest province with the lowest $40 \%$ prosperous households was in East Java of 4,164,259 households (1.83\%) (TNP2K, 2011) and according to BPS, the number of poor people in East Java is the highest in Indonesia, in September 2016 for about 4.63 million (20.34\%) people (BPS, 2017).

There are 10 highest regencies in East Java province with low welfare households, one of them is Jombang Regency with 152,097 households (TNP2K, 2011). In accordance with data from Bappeda (2015), Jombang Regency has economic growth below the provincial average but the poverty reduction was above the average of East Java province (low-growth, pro-poor). Therefore, Jombang District faces the challenge to maintain the effectiveness and efficiency of poverty reduction program and simultaneously can accelerate the regional economic development.

One of the major poverty reduction programs is the Hope Family Program. The evaluation of 13 CCT programs in Latin American countries shows that CCT is effective in increasing the use of preventive health services, improving certain health status and encouraging healthy behavior (Ranganathan and Lagarde, 2012). To evaluate the implementation of CCT in Indonesia, it needs further research to 
know the influence of Family Hope Program on nutritional status and health behavior as well as the influence of mother education, family income, family support, health care access to maternal health behavior. It is also to know the magnitude of the influence of birth weight, history of infant and nutritional intake of nutritional status of infants. Therefore, the researchers are interested in examining the Influence of Family Hope Program on the behavior of maternal health and nutritional status of toddlers poor families.

\section{SUBJECTS AND METHOD}

\section{Study Design}

This was analytic observational with retrospective cohort approach. The study was conducted in Jombang, East Java, from November to December 2017.

\section{Population and Sample}

The target population in this study were all mothers and children under five in poor families in Jombang regency, while the source population in the study were mothers and children in poor families who received Family Hope Program (PKH) and who did not get PKH assistance in Jombang regency. The sample size in this study were 210 subjects selected using Stratified Random Sampling and Fixed Exposure Sampling. Stratified random sampling is done based on the number of residents of underprivileged hence got Plandaan Subdistrict with population of high preprosperous, Ploso Sub-district with population of pre-prosperous and Tembelang subdistrict with low pre-prosperous population. After that, fixed exposure sampling was employed by dividing into exposed and not exposed groups. Research subjects were divided into 2 groups, exposed and unexposed. The exposed group consisted of 105 subjects of mothers and toddlers in poor families who became participants of
Family Hope Program and the unexposed group consisted of 105 subjects that were mothers and toddlers in poor families who were not participants of PKH.

\section{Operational definition of variables}

The operational definition of the Family Hope Program variable is a conditional social assistance program to poor families that are designated as beneficiary families of PKH. The level of education of the mother is the highest formal school level achieved by someone starting from elementary, junior high, high school and college taken by the mother.

Income was defined as a family income generated by working by the head of family / family members or from $\mathrm{PKH}$ assistance that is used to meet daily needs in a month. Family support was defined as the attitude and action of family members in the form of informational support, assessment, instrumental, and emotional support.

Access to health service was defined as how easy the subjects achieve the adequate health facilities based on the distance. The nutritional intake of toddlers was defined as the fulfillment of nutrition of children in the form of food consumed including the frequency, amount, texture, variety, nutritious food, according to their age.

Birthweight was defined as the weight measured one hour after birth, normal weight $\geq 2500$ grams. The history of a infant illness was defined as a disquieting physical and spiritual condition that causes a child not to carry out an activity as well as a healthy person.

Maternal health behavior was defined as all activities or activities undertaken by the mother, both observable and unobservable in relation to the maintenance and improvement of health. Therefore, they can prevent disease, improve health and play an 
Journal of Maternal and Child Health (2018), 3(1): 33-43

https://doi.org/10.26911/thejmch.2018.03.01.04

active role in realizing a healthy environment. Nutritional status is a state of equilibrium between intake and nutrient expenditure in the body and measurements showing the nutritional status of children aged 6 - 59 months as measured by weight index according to age and $\mathrm{Z}$ score classification of nutritional status with WHO-2005 standard calculation and Ministry of Health - 2010.

\section{Data Analysis}

The data analysis of research result used path analysis with program of Stata 13.

\section{Research Ethics}

The research ethical clearance was obtained from the Research Ethics Committee at Dr.

Table 1. Maternal Characteristics
Moewardi Hospital, Surakarta, Central Java, Indonesia. Research ethics included issues such as informed consent, anonimity, confidentiality, and ethical clearance.

\section{RESULTS}

\section{Sample Characteristics}

Characteristics of mothers are shown in Table 1 that the age of mothers were mostly aged 25 to 35 years as many as 193 people and some mothers were working as many as 117 people (55.71\%). Table 2 shows that most infants aged $37-60$ months were 152 (72.38\%). Based on the sex of underfive almost the same between men and women that was $50.95 \%$ and $49.05 \%$.
Characteristic

\begin{tabular}{lcc} 
& & \\
\cline { 2 - 3 } & n = 210 & \% \\
\hline Age & & 34.76 \\
$<25$ years & 17 & 45.71 \\
25 - 35 years & 96 & 46.19 \\
$\geq 35$ years & 97 & 44.29 \\
Occupation & & 55.71 \\
Not Working & 93 & \\
Working & 117 & \\
\hline
\end{tabular}

Table 2. Characteristics of Toddlers

Characteristic

\begin{tabular}{llll}
\hline \multicolumn{1}{c}{ Characteristic } & \multicolumn{2}{c}{ Total } \\
\cline { 2 - 3 } & $\mathbf{n = 2 1 0}$ & \% \\
\hline Age & 7 & 3.33 \\
$7-12$ months & 51 & 24.29 \\
$13-36$ months & 152 & 72.38 \\
37-60 months & & & \\
Gender & 107 & 50.95 \\
Male & 103 & 49.05 \\
Female & & \\
\hline
\end{tabular}

Table 3 shows the nutritional intake of toddlers, most of PKH participants had a good nutritional intake for about 86 people (72.9\%) and not the highest PKH participants had less than 73 children (79.3\%). Maternal health behaviors showed that mothers who were the highest PKH participants had good health behaviors for about
86 people (89.6\%) and mothers who were not the highest $\mathrm{PKH}$ participants had less health behavior (95\%) (83.3\%).

The proportion of nutritional status of children showed that the highest PKH participants had good nutrition status (95 people/67.9\%) and the highest non-PKH mothers had less than $65(85.7 \%)$. The 
history of toddler illness showed that the majority of $\mathrm{PKH}$ participants did not get sick (74 people /60.7\%) and not the highest $\mathrm{PKH}$ participants in the last two weeks were 57 people (64.8\%). Birth weight of children under five in $\mathrm{PKH}$ participants and non PKH participants had a normal birth weight of 100 people $(53.2 \%)$ and 88 people (46.8\%).

\section{Table 3. Univariate Analysis}

\begin{tabular}{|c|c|c|c|c|c|c|}
\hline \multirow{3}{*}{ Variable } & \multicolumn{4}{|c|}{ Family Hope Program (PKH) } & \multirow{2}{*}{\multicolumn{2}{|c|}{ Total }} \\
\hline & \multicolumn{2}{|c|}{ Non Participant } & \multicolumn{2}{|c|}{ Participant } & & \\
\hline & $n=105$ & $\%$ & $\mathbf{n}=\mathbf{1 0 5}$ & $\%$ & $\mathbf{n}=\mathbf{2 1 0}$ & \% \\
\hline \multicolumn{7}{|l|}{ Infants Nutrition Intake } \\
\hline Poor & 73 & 79.3 & 19 & 14.3 & 92 & 100 \\
\hline Good & 32 & 27.1 & 86 & 72.9 & 118 & 100 \\
\hline \multicolumn{7}{|c|}{ Maternal Health Behavior } \\
\hline Poor & 95 & 83.3 & 19 & 16.7 & 114 & 100 \\
\hline Good & 10 & 10.4 & 86 & 89.6 & 96 & 100 \\
\hline \multicolumn{7}{|c|}{ Infants nutritional status } \\
\hline Poor & 60 & 85.7 & 10 & 14.3 & 70 & 100 \\
\hline Good & 45 & 32.1 & 95 & 67.9 & 140 & 100 \\
\hline \multicolumn{7}{|c|}{ Childhood Illness History } \\
\hline Have illness history & 57 & 64.8 & 31 & 35.2 & 88 & 100 \\
\hline Don't have illness history & 48 & $39 \cdot 3$ & 74 & 60.7 & 122 & 100 \\
\hline \multicolumn{7}{|l|}{ Birthweight } \\
\hline Under & 17 & $77.3 \%$ & 5 & $22.7 \%$ & 22 & 100 \\
\hline Normal & 88 & 46.8 & 100 & $53.2 \%$ & 188 & 100 \\
\hline \multicolumn{7}{|l|}{ Family Support } \\
\hline Weak & 83 & 84.7 & 15 & $15 \cdot 3$ & 98 & 100 \\
\hline Strong & 22 & 19.6 & 90 & 80.4 & 112 & 100 \\
\hline \multicolumn{7}{|l|}{ Family Income } \\
\hline Low & 82 & 67.2 & 40 & 32.8 & 122 & 100 \\
\hline High & 23 & 26.1 & 65 & 73.9 & 88 & 100 \\
\hline \multicolumn{7}{|l|}{ Maternal education } \\
\hline Low & 55 & 59.1 & 38 & 40.9 & 93 & 100 \\
\hline High & 50 & 42.7 & 67 & 57.3 & 117 & 100 \\
\hline
\end{tabular}

The support of the families of the highest PKH participant mothers had strong family support of 90 people (80.4\%) and the highest non PKH mothers had weak family support of 83 people ( $84.7 \%)$. The proportion of family income of the highest PKH participants had high income (65 people/73.9\%) and the highest non PKH mothers had a low income of 82 people (67.2\%). The highest level of education of the highest PKH (67.3\%) and the non-PKH (primary school) and primary school (55.3\%) were 55 (59.1\%).

\section{Bivariate Analysis}

Bivariate analysis looks at the relationship of independent variables (expectancy family program, maternal education, family income, family support, access to health services, maternal health behavior, birth weight, history of infant illness, nutrient intake) with dependent variable (nutritional status of children under five and behavior maternal health). 
Journal of Maternal and Child Health (2018), 3(1): 33-43

https://doi.org/10.26911/thejmch.2018.03.01.04

Table 4. Bivariate analysis of factors that affect the nutritional status of children under five years

\begin{tabular}{|c|c|c|c|c|c|c|c|c|c|}
\hline \multirow{3}{*}{ Independent Variable } & \multicolumn{4}{|c|}{ Nutritional Status } & \multirow{2}{*}{\multicolumn{2}{|c|}{ Total }} & \multirow{3}{*}{ OR } & \multirow{3}{*}{$95 \% \mathrm{CI}$} & \multirow{3}{*}{$\mathbf{p}$} \\
\hline & \multicolumn{2}{|c|}{ Poor } & \multicolumn{2}{|c|}{ Good } & & & & & \\
\hline & $\mathbf{n}$ & $\%$ & $\mathbf{n}$ & $\%$ & $\mathbf{n}$ & $\%$ & & & \\
\hline \multicolumn{10}{|l|}{$\begin{array}{l}\text { Family Hope Program } \\
\text { (FHP) }\end{array}$} \\
\hline Not FHP's Participant & 60 & 57.1 & 45 & 42.9 & 105 & 100 & 12.7 & 5.9 to 27 & $<0.001$ \\
\hline FHP's Participant & 10 & 9.5 & 95 & 95 & 105 & 100 & & & \\
\hline \multicolumn{10}{|l|}{$\begin{array}{l}\text { Children Nutritional } \\
\text { Intake }\end{array}$} \\
\hline Poor & 57 & 62 & 35 & 38 & 92 & 100 & 13.2 & 6.4 to 26.9 & $<0.001$ \\
\hline Good & 13 & 11 & 105 & 89 & 118 & 100 & & & \\
\hline \multicolumn{10}{|l|}{ Maternal Health } \\
\hline Poor & 60 & 52.6 & 54 & 47.4 & 114 & 100 & 9.6 & 4.5 to 20.2 & $<0.001$ \\
\hline Good & 10 & 10.4 & 86 & 89.6 & 96 & 100 & & & \\
\hline \multicolumn{10}{|l|}{ History of Illness } \\
\hline Not Sick & 23 & 18.9 & 99 & 81.1 & 122 & 100 & 4.9 & 2.7 to 9.1 & $<0.001$ \\
\hline Sick & 47 & 53.4 & 41 & 46.5 & 88 & 100 & & & \\
\hline \multicolumn{10}{|l|}{ Birthweight } \\
\hline Low & 19 & 86.4 & 3 & 13.6 & 22 & 100 & 17 & 4.8 to 59.9 & $<0.001$ \\
\hline Normal & 51 & 27.1 & 137 & 72.9 & 188 & 100 & & & \\
\hline \multicolumn{10}{|l|}{ Family Support } \\
\hline Weak & 55 & 56.1 & 43 & $43 \cdot 9$ & 98 & 100 & 8.3 & 4.2 to 16.2 & $<0.001$ \\
\hline Strong & 15 & 13.4 & 97 & 86.6 & 112 & 100 & & & \\
\hline \multicolumn{10}{|l|}{ Family Income } \\
\hline Low & 60 & 49.2 & 62 & 50.8 & 122 & 100 & 7.5 & 3.6 to 15.9 & $<0.001$ \\
\hline High & 10 & 11.4 & 78 & 88.6 & 88 & 100 & & & \\
\hline
\end{tabular}

Table 5. Bivariate analysis of the affect of Family Hope Program and maternal education on maternal health behavior

\begin{tabular}{|c|c|c|c|c|c|c|c|c|c|}
\hline \multirow{3}{*}{ Variable } & \multicolumn{4}{|c|}{$\begin{array}{c}\text { Maternal Health } \\
\text { Behavior }\end{array}$} & \multirow{2}{*}{\multicolumn{2}{|c|}{ Total }} & \multirow{3}{*}{ OR } & \multirow{3}{*}{$95 \%$ CI } & \multirow{3}{*}{$\mathbf{p}$} \\
\hline & \multicolumn{2}{|c|}{ Poor } & \multicolumn{2}{|c|}{ Good } & & & & & \\
\hline & $\mathbf{n}$ & $\%$ & $\mathbf{N}$ & $\%$ & $\mathbf{n}$ & $\%$ & & & \\
\hline \multirow{2}{*}{\multicolumn{10}{|c|}{ Family Hope }} \\
\hline \multicolumn{7}{|l|}{ Program (FHP) } & & & \\
\hline Did not participate & 95 & 90.5 & 10 & 9.5 & 105 & 100 & 43.0 & 18.91097 .0 & $<0.001$ \\
\hline Participate & 19 & 18.1 & 86 & 81.9 & 105 & 100 & & & \\
\hline \multicolumn{10}{|l|}{ Maternal } \\
\hline Education & & & & & & & & 2.1 to 6.9 & \\
\hline Low & 67 & 72 & 26 & 28 & 93 & 100 & 3.8 & & $<0.001$ \\
\hline High & 47 & 40.2 & 70 & 59.8 & 117 & 100 & & & \\
\hline
\end{tabular}

\section{The Results of Path Analysis}

Table 6 showed that there was a significant effect of children nutritional intake, birthweight, family support, history of illness, maternal education, Family Hope Program, maternal health behavior, family income on nutritional status and the effect of Family
Hope Program on maternal health behavior. Children nutritional status was affected by good nutritional intake $(b=1.9 ; 95 \%$ $\mathrm{CI}=1.1$ to $2.8 ; \mathrm{p}<0.001)$, normal birthweight $(\mathrm{b}=2.5 ; 95 \% \mathrm{CI}=0.9$ to $4.1 ; \mathrm{p}=$ o.002), strong family support ( $b=1.5 ; 95 \%$ $\mathrm{CI}=0.6$ to 2.3 ; $\mathrm{p}<0.001$ ), and no history of 
illness $(b=1.3$; CI $95 \%=0.5$ to $2.1 ; p=$ 0.001).

Maternal health behavior was affected by high maternal education $(b=1.9 ; 95 \%$ $\mathrm{CI}=0.9$ to $2.8 ; \mathrm{p}<0.001$ ) and participated in Family Hope Program (b= 4.1; 95\% CI= 3.1 to $5.0 ; \mathrm{p}<0.001$ )

Nutritional intake was affected by good maternal health behavior $(b=0.4$; 95\% $\mathrm{CI}=-0.04$ to $0.85 ; \mathrm{p}=0.074)$, high family income $(b=0.6 ; 95 \% \mathrm{CI}=0.2$ to 1.1 ; $\mathrm{p}=0.004)$, and strong family support $(\mathrm{b}=$ $0.9 ; 95 \% \mathrm{CI}=0.5$ to $1.3 ; \mathrm{p}<0.001$ ).

Birthweight was affected by good maternal behaviour $(\mathrm{b}=0.9 ; 95 \% \mathrm{CI}=0.5$ to 1.3; $\mathrm{p}<0.001)$. Family income was affected by high maternal education $(b=1.9 ; 95 \%$ $\mathrm{CI}=1.3$ to $2.6 ; \mathrm{p}<0.001$ ).

Family support was affected by high family income $(b=1.1 ; 95 \% \mathrm{CI}=0.6$ to 1.7 ; $\mathrm{p}<0.001)$. Participating in family hope program was affected by $(b=0.5 ; 95 \% \mathrm{CI}=-$ 0.05 to $1.04 ; \mathrm{p}<0.001)$.

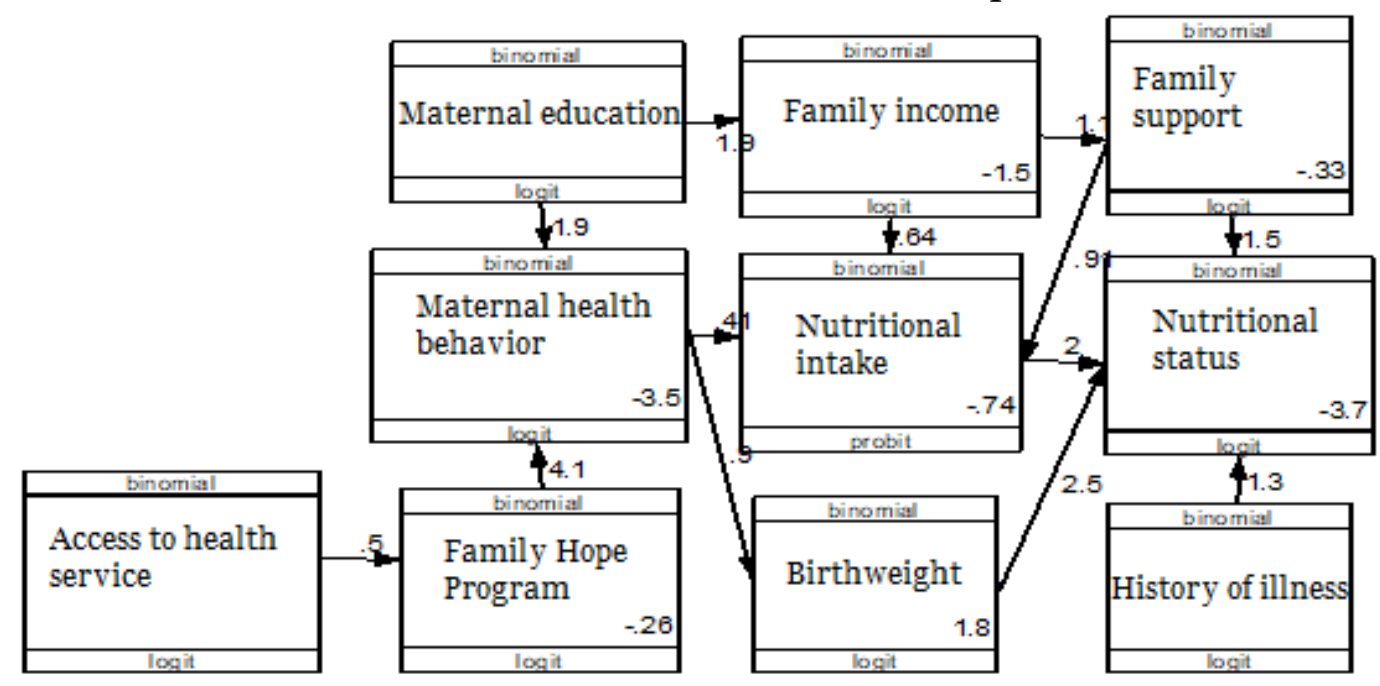

Figure 1. Structural model with estimation

Table 6. Path Analysis Results

\begin{tabular}{|c|c|c|c|c|c|c|}
\hline \multirow[b]{2}{*}{ Dependent Variable } & & \multirow[b]{2}{*}{ Independent Variable } & \multirow{2}{*}{$\begin{array}{c}\text { Path } \\
\text { Coefficient } \\
\text { (b) }\end{array}$} & \multicolumn{2}{|c|}{$95 \%$ CI } & \multirow[b]{2}{*}{$\mathbf{p}$} \\
\hline & & & & $\begin{array}{l}\text { Lower } \\
\text { Limit }\end{array}$ & $\begin{array}{l}\text { Upper } \\
\text { Limit }\end{array}$ & \\
\hline \multicolumn{7}{|l|}{ Direct Effect } \\
\hline Nutritional Status & $\leftarrow$ & Good Nutritional Status & 1.9 & 1.1 & 2.8 & $<0.001$ \\
\hline Nutritional Status & $\leftarrow$ & Normal Birthweight & 2.5 & 0.9 & 4.1 & 0.002 \\
\hline Nutritional Status & $\leftarrow$ & Strong Family Support & 1.5 & 0.6 & 2.3 & $<0.001$ \\
\hline Nutritional Status & $\leftarrow$ & No History of Illness & 1.3 & 0.5 & 2.1 & 0.001 \\
\hline Indirect Effect & & & & & & \\
\hline $\begin{array}{l}\text { Maternal Health } \\
\text { Behavior }\end{array}$ & $\leftarrow$ & High Maternal Education & 1.9 & 0.9 & 2.8 & $<0.001$ \\
\hline $\begin{array}{l}\text { Maternal Health } \\
\text { Behavior }\end{array}$ & $\leftarrow$ & Family Hope Program & 4.1 & 3.1 & 5.0 & $<0.001$ \\
\hline Nutritional Intake & $\leftarrow$ & Good Maternal Behavior & 0.4 & -0.04 & 0.85 & 0.074 \\
\hline Nutritional Intake & $\leftarrow$ & High Family Income & 0.6 & 0.2 & 1.1 & 0.004 \\
\hline Nutritional Intake & $\leftarrow$ & Strong Family Support & 0.9 & 0.5 & 1.3 & $<0.001$ \\
\hline Birthweight & $\leftarrow$ & Good Maternal Behavior & 0.9 & -0.1 & 1.9 & 0.074 \\
\hline Family Income & $\leftarrow$ & High Maternal Education & 1.9 & 1.3 & 2.6 & $<0.001$ \\
\hline Family Support & $\leftarrow$ & High Family Income & 1.1 & 0.6 & 1.7 & $<0.001$ \\
\hline Family Hope Program & $\leftarrow$ & $\begin{array}{l}\text { Easy Access to Health } \\
\text { Services }\end{array}$ & 0.5 & -0.05 & 1.04 & $<0.001$ \\
\hline
\end{tabular}


Journal of Maternal and Child Health (2018), 3(1): 33-43

https://doi.org/10.26911/thejmch.2018.03.01.04

\section{The effect of family hope program on children nutritional status}

The result of this study showed that Family Hope Program affected the toddlers' nutritional status. This study was supported by Ranganathan and Lagarde (2012)who stated that FHP international program called CCT (Conditional Cash Transfer) showed an evaluation of 13 CCT programs in Latin America effectively improve health status and encourage healthy behavior, which was the use of preventive health services. A study by Satriawan (2016) showed that Indonesian CCT Program (FHP) which has been for 6 years can reduce severe stunting.

One of the objectives of FHP was expected as a program that improve access and quality of health services for FHP participants, where poor families were unable to fulfill health needs. The low health condition of poor families has an impact on the non-optimal growth process (Ministry of Social, 2016)

Based on the description above, it can be concluded that there was an indirect relationship between Family Hope Program and children nutritional status through children nutritional intake and maternal health behaviors.

\section{The effect of nutritional intake on children nutritional status}

The result of this study showed that nutritional intake affected children nutritional status. According to the Ministry of Health (2014), foods intake was the most important behavior that can affect the state of nutrition. This is because the quantity and quality of food and beverages consumed will affect the health of individuals and communities. Toddler age is a very important time to determine the future of children. In order to achieve good nutritional status, the improvement of food consumption, both quantity and quality was needed.

In order to keep the body healthy and protected from various chronic diseases or non-transmitted diseases (NTD) associated with nutrition, then the community's dietary habit need to be improved toward balanced nutrition consumption (Ministry of Health, 2014). Based on the description above, it can be concluded that there was a direct relationship between nutritional intake and children nutritional status.

\section{The effect of maternal behavior on children nutritional status}

The result of this study showed that there was an effect of maternal behavior on children nutritional status. The dominant factor which lead to the lack of nutrition was improper behavior in choosing and feeding the children. Feeding practices include breastfeeding, extra food, preparation, and supply of nutritious food. Child cares include nurturing for sick children, immunizations, supplements, and bathing the children. The basic needs of children consist of food, health care, and affection. As the person who determined the food to be purchased, cooked and prepared, the mothers play an important role in the food management for toddlers (Ministry of Health, 2014)

Based on the description above, it can be concluded that there was an indirect relationship betweenmaternal health behavior and toddlers' nutritional statusthrough nutritional intake and birthweight.

\section{The effect of birthweight on children nutritional status}

The result of this study showed that there was an effect of birthweight on children nutritional status.This was in accordance with a study by Oliveira (2013) which stated that birthweight was a variable that significantly influence the nutritional status of toddlers based on the length of age by $3.8 \%$ and 12.8\% (Oliveira et al., 2013). 
Low birthweight was associated with increased coronary heart disease, stroke, hypertension, obesity, insulin resistance and type 2 diabetes. Impaired growth in prenatal and childhood would worsen health conditions in adulthood. Optimal development in prenatal and early growth periods provided a good long-term impact on the development of children to adulthood (Barker, 2004).

Based on the description above, it can be concluded that there wasa direct relationship between birthweight and children nutritional status.

\section{The effect of family support on children nutritional status}

The result of this study showed that family support affected the children nutritional status.This study was in accordance with a study by Helena (2017) which stated that there was a relationship between family support in the fulfillment of child nutrition and children nutritional status. It was influenced by good family support, therefore, the family can provide good food for their children. Conversely, if the support of the family was weak, then the nutritional status of the child would also be a problematic.

According to Friedman (2010), family support is a form of interpersonal relationships that include attitudes, actions and acceptance so that family members feel cared for. Based on the description above, it can be concluded that there wasa direct relationship between family support and children nutritional status.

\section{The Effect of History of Illness on Toddlers' Nutritional Status}

The result of this study showed that there was an effect ofillness history on children nutritional status. According to Suskind and Lenssen (2013), diseases that can affect the adequacy of nutritional intake include vomiting, diarrhea, constipation, sucking or chewing problems, abdominal pain, respiratory distress, heart failure, kidney failure and all chronic diseases.

Children with body infection need more nutrients to fulfill the enhancement of metabolism of people suffering from infection, especially with heat.In people who have diarrheal diseases, they would experience the loss of nutrients and fluids directly so that it would worsen their condition(Ministry of Health, 2014)

Based on the description above, it can be concluded that there wasa direct relationship between toddlers' illness history and toddlers' nutritional status.

\section{The effect of maternal education on children nutritional status}

The result of this study showed that maternal education affected the toddlers' nutritional status. Determinants level of parental education were considered as important determinants of nutritional status in children which affected the malnutrition (Kamiya, 2011). A study by Syed and Rao, (2015) showed that there was a significant relationship between the adequacy of maternal knowledge about nutrition and children nutritional status.

Based on the description above, it can be concluded that there wasanindirect relationship between maternal education and children nutritional status through income, nutritional intake, and family support.

\section{The effect of family income on children nutritional status}

The result of this study showed that there was an effect of family income on children nutritional status. This study was in accordance with Syed and Rao (2015), which stated that there was a significant relationship between per capita income factors and children nutritional status. According to Kamiya (2011) dan Mulugeta et al. (2017), an important determinant 
affecting malnutrition was the amount of household wealth status as a critical determinant of nutritional status in children.

Nutritional status based on body weight per age has influencing factor that was socioeconomic (Sartika, 2010). The cause of malnutrition among children came from the socioeconomic condition (Kamiya, 2011). Based on the description above, it can be concluded that there wasan indirect relationship between family income and children nutritional status through nutritional intake and family support.

\section{The effect of family hope program on maternal health behavior}

The result of this study showed that there was an effect ofFamily Hope Program on maternal health behavior. According to Ranganathan and Lagarde (2012), CCT programs effectively support poor families to behave healthily. According to The National Team for the Acceleration of Poverty Reduction (TNP2K) (2011), FHP have a positive and real impact in improving the healthy behavior of FHP program beneficiaries, including the number of visits of pregnant women and postpartum women to health facilities, children weighed, and delivery in health service facilities.

FHP was provided after verification before and after the family who recieved the benefit of FHP conducted pregnancy check up, delivery at health facility, weighing, and medical examination (The World Bank, 2012). Access to health was expected to change the behavior of poor people to be more concerned about improving access and quality of health services (Ministry of Social, 2016). Based on the description above, it can be concluded that there wasa direct relationship between Family Hope Program and children nutritional status.

\section{The effect of access to health services on maternal health behavior}

The result of this study showed that health services access affected the maternal health behavior through Family Hope Program. According to the Ministry of Social (2016), FHP impact was stronger in areas with better health facilities.

According to Bbaale (2014), the use of health was an important factor affecting the health status of children, including whether a mother received prenatal care from a doctor or nurse, giving birth with the attention of a doctor or nurse or not.Based on the description above, it can be concluded that there wasa relationship between access to health services and Family Hope Program.

\section{REFERENCES \\ Adisasmito W (2008). Analisis Kemiskinan, MDGs dan Kebijakan Kesehatan Nasional. \\ WHO (2016). WHO Children reducing mortality 2016: 3-7. \\ Bbaale E (2014). Maternal education and child nutritional status: evidence from Uganda, African Journal of Economic and Management Studies, 5(1): 52- 74. doi: 10.1108/AJEMS-06-2012- 0040. \\ BPS (2017). Profil Kemiskinan di Indonesia 2016, Berita Resmi Statistik, (5): 1-9. \\ (2014). Badan Pusat Statistik (Sta- tistics Indonesia) Agriculture and Mining Plantation.}

Forde I, Rasanathan K, and Krech R (2011) Public health agencies and cash transfer programmes: making the case for greater involvement, (Avenue Appia 201211 Geneva 27, Switzerland.doi: 10.2471/BLT.11.097733.

Kamiya Y (2011). Socioeconomic Determinants of Nutritional Status of Child- 
ren in Lao PDR Effects of Household and Community Factors, $\mathrm{J}$ Health Popul Nutr, 29(4): 339-348. doi: 10.3329/jhpn.v29i4.8449.

Kemenkes (2014). Pedoman Gizi Seimbang, Riskesdas.

Kemsos (2016) Program Keluarga Harapan Tahun 2016.

Lesiapeto MS (2009). Factors associated with nutritional status of children aged o-6o months residing in Eastern Cape and KwaZulu-Natal Provinces.

Oliveira JS, et al. (2013) Fatores associados ao estado nutricional em criancas de creches publicas do municipio de Recife, PE, Brasil, Revista Brasileira de Epidemiologia, 16(2): 502-512.

Ranganathan M, Lagarde M (2012). Promoting healthy behaviours and improving health outcomes in low and middle income countries: A review of the impact of conditional cash transfer programmes, Preventive Medicine. Elsevier BV, 55: S95-S105.

Sartika RAD (2010). Analisis Pemanfaatan
Program Pelayanan Kesehatan Status Gizi Balita. Kesmas: National Public Health Journal, 5(2), pp. 90-96.

Satriawan E (2016).Evaluating Longer-term Impact of Indonesia's CCT Program: Evidence From Randomised Control Trial JPAL SEA Conference on Social Protection, (January).

BPS (2007). Tingkat Kemiskinan di Indonesia Tahun 2007, (38): 1-5.

Syed S, Rao R (2015) Factors influencing nutritional status of school children in an urban slum of Hyderabad India, International Journal Contemporary Pediatrics, 2(4): 335-339.

The World Bank (2012) PKH Conditional Cash Transfer. Social Assistance Program and Public Expenditure Review 6: 34 .

Bappeda (2015).Seri Analisis Pembangunan Wilayah Provinsi Jawa Timur 2015.

TNP2K (2011). Program bantuan sosial dan penanggulangan kemiskinan.

WHO (2015).Under-five mortality. 